\section{Rows floor factory project}

\section{Tokyo \& Washington}

When Hiroyuki Yoshikawa of the University of Tokyo proposed the Intelligent Manufacturing System (IMS) project to develop automated factories of the future, his dream was to redress the imbalances in world trade by systematizing manufacturing technology so that it can be transferred easily to developing nations. But instead, IMS is turning into a struggle between the economic giants of the world over control and organization of the yetto-be realized project.

Representatives of the US Department of Commerce (DOC), Japan's Ministry of International Trade and Industry (MITI) and the European Communities (EC) at a recent meeting in Tokyo agreed on a strategy for launching a feasibility study for IMS early next year. However, fundamental differences remain between the three sides on how to organize the project and in particular how to handle intellectual property rights arising out of the research.

Under IMS, international research consortia drawn from government, industry and academic institutions will develop standardized manufacturing systems that are fully computerized from the design of a product through to its retail and distribution. In addition to dozens of Japanese companies that have signed up for the project, many of the world's largest multinational companies have also expressed interest in joining, including Rolls-Royce, Fiat, Philips and Siemens from Europe, and Rockwell International, United Technologies, Pratt and Whitney, IBM, DEC, Kodak, AT \& T, General Motors and General Electric from the United States. And although it is government officials who are discussing the organization of the project, much of the input comes

ISRAEL-SOVIET UNION

\section{Working together}

\section{Jerusalem}

ISRAEL and the Soviet Union have signed a scientific agreement in Jerusalem that paves the way for three years of joint research.

Last week's signing ceremony capped a week-long visit by a 16-member delegation from the Soviet Academy of Sciences, headed by its president, Professor Gury Marchuk.

Israeli Science and Technology Minister Yuval Ne'eman, himself a renowned physicist, called the agreement a "real breakthrough" in the scientific field and in the nature of diplomatic relations between the two countries. The Soviet Union broke off relations with Israel in 1967.

Lisa Perlman from industry representatives.

Top of the agenda at last month's meeting in Tokyo was a US proposal on how IMS should be run, which follows earlier proposals from Japan and the EC (see Nature 347, 320; 1990). A detailed outline of the US proposal, still confidential, shows that on the contentious issue of intellectual property rights, the United States puts strong emphasis on the region of origin of any invention made under IMS so that US inventions will benefit US companies first and foremost.

Japan, on the other hand, in a proposal issued in February, calls for a significant part of intellectual property rights to be held by a central IMS organization to which all IMS participants from all countries would have access in much the same way as Japanese companies share access to inventions resulting from national MITI projects. The EC in turn have put forward detailed rules that would assign rights according to the relative contributions of companies to an invention regardless of where it is is made.

Another contentious issue is the areas of research on which the project will focus. MITI officials say they want to cover all areas of automated manufacturing. But the US government and the EC suspect that Japan is targeting US and European expertise in software, artificial intelligence and systems integration.

The draft US proposal circulated in Washington a few months ago calls for the United States to develop a 'lightning rod' IMS proposal that focuses attention on areas in which US industry is weak but Japan and Europe are strong, for example process technology and precision tooling and engineering.

And, according to participants at the Tokyo meeting, the US representatives were particularly insistent about US interest in these areas. In contrast, the EC position is that only partners of "equal strength" should participate in IMS projects.

Also yet to be resolved is the mechanism of funding. Japan proposed a central IMS organization funded with contributions from all participants, and such an organization is already in place in Tokyo with a fund of several million dollars donated from dozens of Japanese companies. The US proposal also calls for a central fund. But the EC insist that IMS should be a decentralized project with each region and each consortium funding its own research, much as in the case of the EC's ESPRIT project. All of these issues will have to be tackled in next year's feasibility study.

Hidehiko Nishiyama, deputy director of MITI's industrial machinery division, hopes to start some pilot IMS projects in approximately eight months.

Further complications arise with other countries that wish to join. Canada, Australia and the European Free Trade Association were represented by observers at the Tokyo meeting and are expected to participate in the feasibility study as independent members. And the United States is pushing for IMS to be open to even more countries.

David Swinbanks \& Chris Anderson AGRICULTURAL BIOTECHNOLOGY -

\section{Tables laid for transgenic tomatoes}

\section{San Francisco}

DEVELOPERS of genetically engineered plants brought their products one tentative but important step closer to the American dinner table last week when Calgene, Inc. asked the US Food and Drug Administration (FDA) for a preliminary opinion on the use of a selectable genetic marker. This is the first time the FDA has been asked to evaluate a component of engineered plants which are to be consumed directly as food.

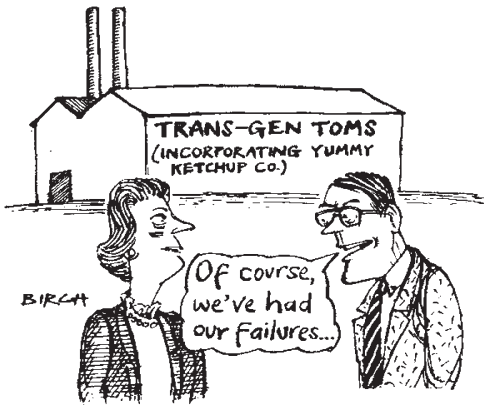

Although the gene, which confers plant cell resistance to the antibiotic kanamycin, is only a tool to help identify the sites of other genes introduced, its approval is expected to speed up future approval of engineered food crops. The gene was recently approved for human gene therapy and is being used in clinical tests.

Calgene, of Davis, California, wants to use the gene in tomatoes altered for enhanced flavour, and in genetically engineered cotton and rapeseed. Calgene's chief executive officer, Roger Salquist, claims this is the first such proposal submitted and will initiate the FDA's study of this new domain.

Calgene intends to file for approval of other products in the next 6-12 months for review in parallel with the kanamycinresistance gene proposal, and it expects a decision within two years. In the wake of Calgene's move, other biotechnology companies are likely to submit plant products for approval. The company set a precedent before when it was the first to be granted permission for field trials by the US Department of Agriculture.

Elizabeth Schaefer 